\title{
Mixing effect on volume growth of Fagus sylvatica and Pinus sylvestris is modulated by stand density
}

\author{
Sonia Condés ${ }^{\mathrm{a}, *}$, Miren Del Rio ${ }^{\mathrm{b}, \mathrm{c}}$, Hubert Sterba ${ }^{\mathrm{d}}$ \\ ${ }^{a}$ Dept. Economía y Gestión Forestal, Escuela Técnica Superior de Ingenieros de Montes, Universidad Politécnica de Madrid, Ciudad Universitaria s/n, 28040 Madrid, Spain \\ ${ }^{\mathrm{b}}$ Dept. Selvicultura y Gestión de Sistemas Forestales INIA-CIFOR, Ctra. A Coruña, km 7.5, 28040 Madrid, Spain \\ ' Sustainable Forest Management Research Institute UVa-INIA, Spain \\ ${ }^{\mathrm{d}}$ Dept. of Forest and Soil Sciences, BOKU University of Natural Resources and Life Sciences, Peter Jordanstrasse 82, Vienna, Austria
}

\section{A R T I C L E I N F O}

\section{Article history:}

Received 25 August 2012

Received in revised form 4 December 2012

Accepted 8 December 2012

Available online 23 January 2013

\section{Keywords:}

Growth model

Growth efficiency

Mixed stands

Mixed and pure stands comparison

Volume increment

\begin{abstract}
A B S T R A C T
Despite the increasing relevance of mixed stands due to their potential benefits; little information is available with regard to the effect of mixtures on yield in forest systems. Hence, it is necessary to study inter-specific relationships, and the resulting yield in mixed stands, which may vary with stand development, site or stand density, etc. In Spain, the province of Navarra is considered one of the biodiversity reservoirs; however, mixed forests occupy only a small area, probably as a consequence of management plans, in which there is an excessive focus on the productivity aspect, favoring the presence of pure stands of the most marketable species.

The aim of this paper is to study how growth efficiencies of beech (Fagus sylvatica) and pine (Pinus sylvestris) are modified by the admixture of the other species and to determine whether stand density modifies interspecific relationships and to what extent.

Two models were fitted from Spanish National Forest Inventory data, for P. sylvestris and F. sylvatica respectively, which relate the growth efficiency of the species, i.e. the volume increment of the species divided by the species proportion by area, with dominant height, quadratic mean diameter, stocking degree, and the species proportions by area of each species. Growth efficiency of pine increased with the admixture of beech, decreasing this positive effect when stocking degree increased. However, the positive effect of pine admixture on beech growth was greater at higher stocking degrees. Growth efficiency of beech was also dependent on stand dominant height, resulting in a net negative mixing effect when stand dominant heights and stocking degrees were simultaneously low.

There is a relatively large range of species proportions and stocking degrees which results in transgressive overyielding: higher volume increments in mixed stands than that of the most productive pure pine stands. We concluded that stocking degree is a key factor in between-species interactions, being the effects of mixing not always greater at higher stand densities, but it depends on species composition.
\end{abstract}

(c) 2012 Elsevier B.V. All rights reserved.

\section{Introduction}

The relationship between species diversity and productivity is a relevant issue in forestry given the increased prominence of mixed stands due to their potential benefits (Kelty, 2006). Within this area of research, a number of studies have focused on the general theory relating forest species diversity and productivity (Erskine et al., 2005; Vila et al., 2007; Belote et al., 2011), while others have tackled the comparison of productivity in pure and mixed stands for specific species compositions (Brown, 1992; Kelty, 1992; Amoroso and Turnblom, 2006; Pretzsch et al., 2010). Most of these latter studies have been developed for mixtures of two species under

\footnotetext{
* Corresponding author. Tel.: +34 913366397.

E-mail address: sonia.condes@upm.es (S. Condés).
}

particular growth conditions, but it is difficult to generalize as regards the mixture effect on yield in forest systems (SchererLorenzen et al., 2005).

Reduced competition and facilitation between forest species growing in mixed stands can result in greater productivity of mixtures (Kelty, 1992). The complementarity between species frequently leads to overyielding (i.e. yield in mixed stands above the average for each species in their respective pure stands), and even transgressive overyielding in some cases (Pretzsch and Schütze, 2009), that is, yield in mixed stands greater than that of the most productive species in pure stands. If there is a lack of complementarity between species or it is not matched to site limiting factors overyielding does not occur (Kelty and Cameron, 1995), while underyielding can be also found under some site and stand conditions (Pretzsch et al., 2010). 
Inter-specific relationships, and the resulting yield in mixed stands, may vary with stand development, site or stand density (Jogiste, 2000; Garber and Maguire, 2004; Pretzsch et al., 2010; Cavard et al., 2011). The spatial arrangement and density of plants are critical factors in the interspecific relationships as many competitive events are less important or disappear altogether when densities are defective (Kelty and Cameron, 1995; Amoroso and Turnblom, 2006). Consequently, niche complementary between species and the corresponding competition reduction may be more evident at high densities where above- and below-ground resources per tree are more limited. In the same way, the spatial arrangement of species is also an important factor as reduction of competition can be lower when mixture pattern tends towards grouping (Pretzsch et al., 2012).

One of the main obstacles to research in this area is the difficulty associated with obtaining quality experimental data for comparing the productivity of pure stands and different mixtures under similar stand and site conditions. A number of studies have been based on data from experiments following a replacement series (Forrester et al., 2004; Amoroso and Turnblom, 2006; Bristow et al., 2006), but such trials are frequently carried out using fast growing species such as eucalyptus, which allow us to obtain results within a reasonable time span. Other studies have made use of long term experimental plots in order to compare the productivity of pure and mixed stands (Pretzsch et al., 2010). However, such data are not available at present for many forest species compositions.

In the absence of this kind of data, forest modeling and/or the use of large-scale forest inventories provide alternatives for comparing productivity in mixed and pure stands (Bartelink, 2000; Vallet and Pérot, 2011). A wide variety of modeling approaches have been employed in the study of interspecific competition relationships, from mechanistic models to empirical models. The scales used have also differed, tree, size classes or stand levels (Pretzsch, 1999; Porté and Bartelink, 2002). Río and Sterba (2009) used national forest inventory data and an empirical stand level approach based on the concept of maximum basal area according to Sterba (1987) to compare the volume growth in pure and mixed pineoak stands growing at different densities. This maximum basal area allows stand density to be estimated in pure and mixed stands in a comparable way, as well as permitting the species proportion by area to be calculated, thereby defining the mixture composition, taking into consideration the different growth potentiality of each species (von Laer cit. Prodan, 1959; Sterba, 1998).

In this paper, the above approach has been used, the main objectives being to study the effect of the admixture one species on volume growth and to analyze the possible interactions between density and mixing effects. This method allows us to determine the mix proportions which lead to transgressive overyielding in mixed stands. The chosen mixtures were those formed by beech and Scots pine growing in northern Spain. In many of the areas where such mixtures could grow in Spain, management plans have favoured the presence of pure stands of the most marketable species, frequently Scots pine, replacing the other species. Over recent decades, mixed stands have been encouraged (MMA, 2002) although the consequences of changes in species composition as regards stand productivity are not known.

Our main hypothesis is that stand density modifies the effect of mixing species; the effect of admixture species being greater at high stand densities. The specific objectives of this work are therefore: (a) to assess the extent to which growth efficiency in Fagus sylvatica L. and Pinus sylvestris L. is modified by the admixture of the other respective species; (b) to determine whether stand density modifies interspecific relationships and to what extent; and (c) to identify whether overyielding, transgressive overyielding or non-mixing effects occurs in this mixture.

\section{Materials and methods}

\subsection{Study area}

The study area is located in the province of Navarra in the North of Spain, (UTM zone 30N, X 545000-678000; Y 4701000-4794000) (Fig. 1). In this region beech is currently the main species in terms of extension and importance, covering approximately 132,000 ha, which accounts for a third of the total beech distribution in Iberian Peninsula. Scots pine has frequently replaced the preexisting oak and beech forests in some forests of this region and now covers an area of 59,000 ha, making it the second most important forest type (Navarra, 2000).

To study the influence of stand composition and density on volume increment, 695 sample plots of the Spanish National Forest Inventories (SNFI) were used (Fig. 1). These included all the plots in the province of Navarra, within an altitudinal range between 400 and $800 \mathrm{~m}$, located in pure stands of $P$. sylvestris and $F$. sylvatica as well as mixed stands in which these species were present (Table 1 ). Table 2 shows the distribution of these plots by altitude and slope classes for pure and mixed stands.

SNFI plots are located at the nodes of a one kilometer square grid and consist of four concentric sample circles of 5, 10, 15 and $25 \mathrm{~m}$ radius, where diameters and heights of all trees over 7.5, $12.5,22.5$ and $42.5 \mathrm{~cm}$ breast height diameter respectively are measured. In this study, data from the Third and the Fourth SNFI were used, carried out in 1999 and 2008 respectively. The main stand variables at the beginning of the studied growth period for the selected plots are shown in Table 1.

A wider data set was used for studying the maximum basal area according to the Competition Density Rule (see next section). It includes additional plots located in pure stands of the studied species from the Third SNFI in adjacent provinces. A total of 1047 plots were used: 221 for $P$. sylvestris and 826 plots for $F$. sylvatica. The main stand variables for these plots can be seen in Table 3 .

\subsection{Species proportion by area}

To determine the proportion of each species in mixed stands the species proportion by area was used. According to von Laer (Prodan, 1959), this can be calculated as:

$P_{i}=\frac{\frac{G_{i}}{G_{\text {max }}}}{\sum_{i} \frac{G_{i}}{G_{\max _{i}}}}$

where for each of the $i$ species $P_{i}$ is the species proportion by area, $G_{i}$ is the observed basal area per hectare and $G_{\max _{i}}$ is the maximum or potential basal area of species $i$ per hectare in a pure stand. The numerator is the area of a fully stocked pure stand of species $i$ needed to exhibit the observed basal area $\left(G_{i}\right)$, and the denominator is the total area of fully stocked pure stands of all species together exhibiting $G_{i}$ respectively (Sterba, 1998).

Thus, it is necessary to determine the maximum or potential basal area for the two studied species. The method used was that developed by Sterba (1987) and described in detail by Río and Sterba (2009). This method is based on the Competition Density Rule defined by Kira et al. (1953) and modified by Goulding (1972), who relates the quadratic mean diameter $d_{g}$ to the stand density $N$ and the dominant height $H_{d o m}$ through the following equation:

$d_{g}=\frac{1}{a_{0} H_{d o m}^{a_{1}} N+b_{0} H_{d o m}^{b_{1}}}$

Sterba (1987) showed that by calculating the basal area from this rule and setting the first derivative $d G / d N$ to zero, the maximum basal area can be obtained: 


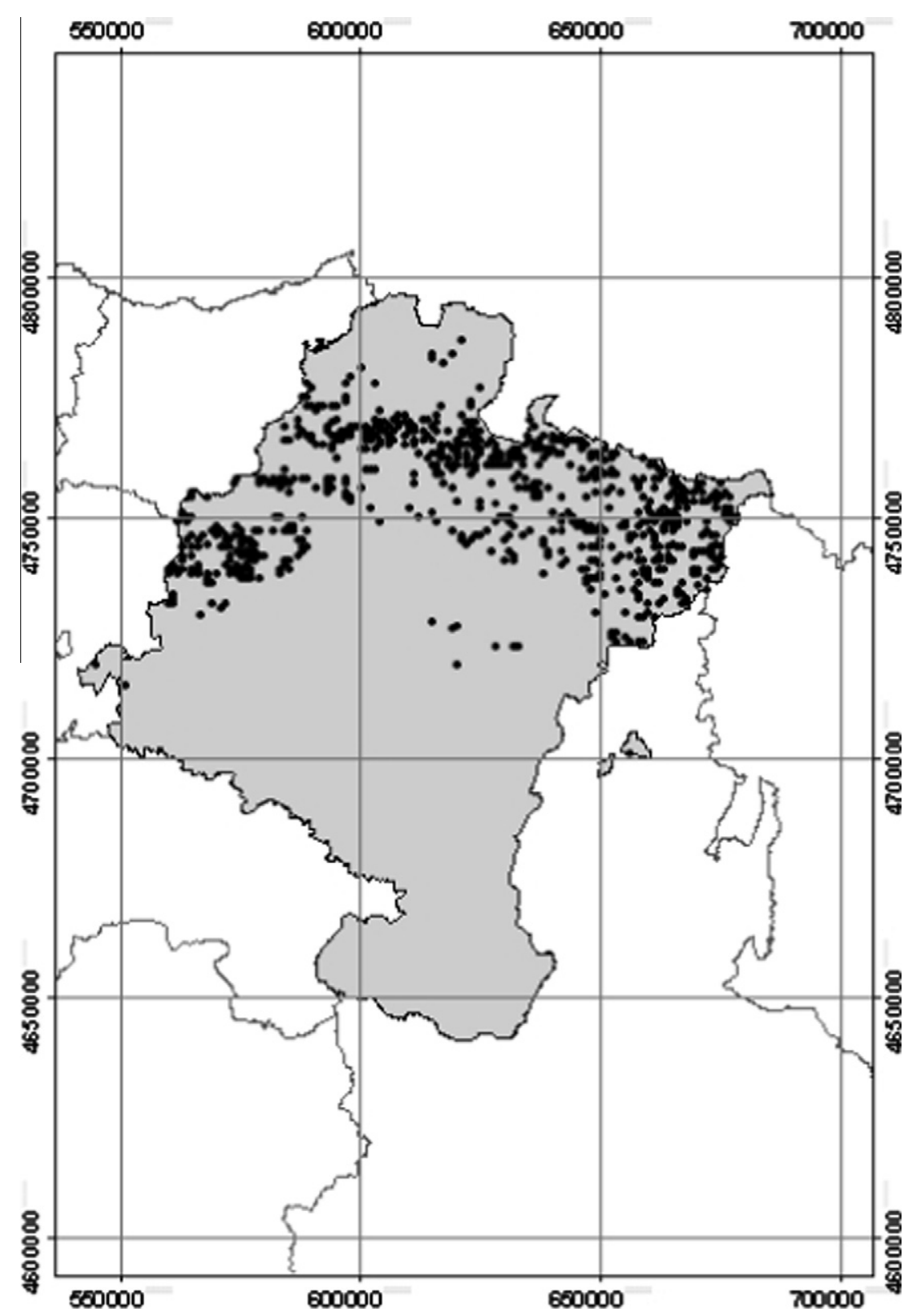

Fig. 1. Location of NFI plots in the Spanish province of Navarra with a UTM grid coordinates zone $30 \mathrm{~N}$.

$$
G_{\text {max }}=\frac{\pi}{160,000 a_{0} b_{0}} H_{d o m}^{-\left(a_{1}+b_{1}\right)}
$$

where $a_{0}, a_{1}, b_{0}$ and $b_{1}$ are parameters that can be estimated from plot data for $d_{g}, H_{d o m}$ and $N$ by means of nonlinear regression. However, Sterba (1987) developed the method in order to make the Competition Density Rule compatible with Reineke's maximum stand density (Reineke, 1933). Thus, given the maximum stand density according to Reineke's expression

$N_{\text {max }}=C d_{g}^{E}$

where the parameters $C$ and $E$ depend on the species, the Competition Density Rule (Eq. (2)) can be written depending on these parameters as follows (Río and Sterba, 2009):

$d_{g}=\frac{1}{\frac{b_{0}}{C}\left(2 b_{0}\right)^{E} H_{d o m}^{a_{1}} N+b_{0} H_{d o m}^{\frac{a_{1}}{E+1}}}$

If the parameters $C$ and $E$ are known for one species (maximum density line), the only two parameters to be estimated from plot data are $a_{1}$ and $b_{0}$, and maximum basal area can be calculated as:

$$
G_{\max }=\frac{\pi}{160,000 \frac{b_{0}}{C}\left(2 b_{0}\right)^{E} b_{0}} H_{d o m}^{-\left(a_{1}+\frac{a_{1}}{E+1}\right)}
$$

To implement this methodology, plot data from pure stands (given in Table 3 ) were used. In a first step Reineke's maximum stand density was obtained for the two studied species. Values of the coefficient $E$ (Eq. (4)) for each species were taken from previous studies. Hence, for $P$. sylvestris the value obtained by Río et al. (2001) $E_{\text {Pinus }}=-1.75$ was used and for $F$. silvatica the value proposed by Pretzsch and Biber (2005) $E_{\text {Fagus }}=-1.789$. The $C$ parameters were then estimated as the mean for the ten plots of each species with maximum density values in order to obtain the maximum density line. The number of ten plots has been used rather to use the plot with maximum density value to avoid singularities. The Competition Density Rule, depending on two parameters (Eq. (5)), was then fitted for the two studied species again using the pure stand data from the Third SNFI (Table 3). The parameters $b_{0}$ and $a_{1}$ in that equation were estimated by non-linear regression 
Table 1

Main stand variables at the beginning of the growth period for pure and mixed plots used in growth efficiency models.

\begin{tabular}{|c|c|c|c|c|c|c|c|}
\hline Species & No plots & & $N$ (trees/ha) & $G\left(\mathrm{~m}^{2} / \mathrm{ha}\right)$ & $H_{\text {dom }}(\mathrm{m})$ & $d_{g}(\mathrm{~cm})$ & $I V\left(\mathrm{~m}^{3} \mathrm{ha}^{-1}\right.$ year $\left.^{-1}\right)$ \\
\hline \multirow[t]{4}{*}{ Pinus sylvestris pure stands } & 174 & Mean & 624.12 & 22.76 & 13.34 & 22.03 & 4.18 \\
\hline & & sd & 440.87 & 15.27 & 4.80 & 6.04 & 2.68 \\
\hline & & Min & 14.15 & 0.50 & 3.80 & 7.55 & 0.06 \\
\hline & & Max & 2581.85 & 82.70 & 27.82 & 44.97 & 12.89 \\
\hline \multirow[t]{4}{*}{ Pinus sylvestris mixed stands } & 69 & Mean & 426.08 & 22.27 & 18.75 & 30.08 & 3.63 \\
\hline & & sd & 423.57 & 17.55 & 4.99 & 9.46 & 2.64 \\
\hline & & Min & 5.09 & 0.70 & 8.27 & 12.59 & 0.11 \\
\hline & & Max & 2394.40 & 73.14 & 30.23 & 56.35 & 9.62 \\
\hline \multirow[t]{4}{*}{ Fagus sylvatica pure stands } & 452 & Mean & 494.16 & 26.82 & 21.64 & 32.59 & 3.49 \\
\hline & & sd & 430.05 & 10.69 & 5.02 & 13.46 & 1.77 \\
\hline & & Min & 5.09 & 0.82 & 6.00 & 8.65 & 0.10 \\
\hline & & Max & 3140.23 & 60.31 & 36.87 & 98.04 & 12.49 \\
\hline \multirow[t]{4}{*}{ Fagus sylvatica mixed stands } & 69 & Mean & 451.14 & 12.13 & 15.35 & 26.32 & 2.32 \\
\hline & & sd & 572.10 & 11.56 & 4.83 & 21.48 & 2.49 \\
\hline & & Min & 5.09 & 0.44 & 6.50 & 7.65 & 0.01 \\
\hline & & Max & 2769.30 & 44.40 & 29.00 & 114.80 & 16.87 \\
\hline \multirow[t]{4}{*}{ Total mixed stands } & 69 & Mean & 877.22 & 34.40 & 19.36 & 25.76 & 5.95 \\
\hline & & sd & 586.14 & 13.38 & 4.84 & 10.76 & 2.72 \\
\hline & & Min & 40.74 & 12.74 & 8.74 & 12.24 & 0.77 \\
\hline & & Max & 2986.60 & 77.52 & 30.27 & 78.72 & 17.37 \\
\hline
\end{tabular}

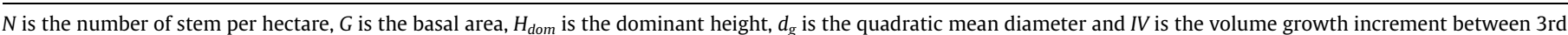
and 4th SNFI.

Table 2

Altitude and slope distribution for pure and mixed plots used in growth efficiency models.

\begin{tabular}{|c|c|c|c|c|c|c|}
\hline Altitude class & $4 \mathrm{Hm}$ & $5 \mathrm{Hm}$ & $6 \mathrm{Hm}$ & $7 \mathrm{Hm}$ & $8 \mathrm{Hm}$ & Total \\
\hline Pinus sylvestris & 60 & 50 & 38 & 24 & 2 & 174 \\
\hline Mixed & 2 & 12 & 40 & 13 & 2 & 69 \\
\hline Fagus sylvatica & 83 & 187 & 141 & 39 & 2 & 452 \\
\hline Slope class & $1\left(0-1.9^{\circ}\right)$ & $2\left(2-7.6^{\circ}\right)$ & $3\left(7.7-12.6^{\circ}\right)$ & $4\left(12.6-21.4^{\circ}\right)$ & Total & \\
\hline Pinus sylvestris & 1 & 70 & 88 & 15 & 174 & \\
\hline Mixed & 2 & 22 & 28 & 17 & 69 & \\
\hline Fagus sylvatica & 7 & 205 & 198 & 42 & 452 & \\
\hline
\end{tabular}

Table 3

Main stand variables of pure plots used to fit the Competition Density Rule (variables as in Table 2).

\begin{tabular}{|c|c|c|c|c|c|c|}
\hline Species & $\mathrm{N}^{\circ}$ plots & & $N$ (trees/ha) & $G\left(\mathrm{~m}^{2} / \mathrm{ha}\right)$ & $H_{\text {dom }}(\mathrm{m})$ & $d_{g}(\mathrm{~cm})$ \\
\hline \multirow[t]{4}{*}{ Pinus sylvestris } & 221 & Mean & 803.3 & 28.69 & 13.44 & 22.17 \\
\hline & & sd & 513.8 & 16.56 & 4.74 & 6.94 \\
\hline & & Min & 14.2 & 0.47 & 3.50 & 7.55 \\
\hline & & Max & 2390.9 & 82.70 & 27.82 & 48.66 \\
\hline \multirow[t]{4}{*}{ Fagus sylvatica } & 826 & Mean & 533.3 & 27.15 & 21.26 & 32.46 \\
\hline & & sd & 488.7 & 11.34 & 5.37 & 14.96 \\
\hline & & Min & 5.19 & 0.59 & 4.00 & 7.70 \\
\hline & & Max & 3140.2 & 64.17 & 36.87 & 110.10 \\
\hline
\end{tabular}

$N$ is the number of trees per hectare, $G$ is the basal area, $H_{d o m}$ is the dominant height, $d_{g}$ is the quadratic mean diameter.

using the "nls" R function (R, 2011). Finally, we were able to calculate the maximum basal area (Eq. (6)) and the species proportion by area (Eq. (1)) for any given stand dominant height.

\subsection{Stand volume increment}

Due to the specific characteristics of the Spanish National Forest Inventory plots, a specific methodology is required to calculate stand volume growth in each plot. If this circumstance is not taken into account, negative values for growth per hectare may result, since a different minimum dbh value is considered for each sampling radius. The method proposed by Hébert et al. (2005) has been used in this study. Thus, the volume growth has been calculated as:
$I V=\frac{\Delta V_{s}+\Delta V_{m}+\Delta V_{c}+\Delta V_{i}}{t_{2}-t_{1}}$

where $I V$ is the mean periodic volume growth measured in $\mathrm{m}^{3}$ ha $^{-1}$ year $^{-1}$, and $\Delta V_{s}, \Delta V_{m}, \Delta V_{c} y \Delta V_{i}$ are volume increments corresponding to survival, mortality, harvest and ingrowth during the period between inventories respectively, while $t_{1}$ and $t_{2}$ are the years in which the initial and final inventories were carried out.

The volume of individual trees has been calculated with volume equations provided by the SNFI. In the case of trees that either died or were felled between inventories, given the lack of precise data as to the date on which the harvest took place or the dbh at that time, it has been assumed that trees were cut at the midpoint of the period between inventories and the $\mathrm{dbh}$ at that time was 
calculated from the initial dbh and the estimated diameter increment. Volume growth was calculated for each species in each of the 695 plots (Table 1 ).

\subsection{Growth efficiency}

When the proportion by area $\left(P_{i}\right)$ for one species in a mixed stand is calculated as described above, the growth efficiency $I V p_{i}$ of species $i$ can be defined as the volume increment of species $I V_{i} \mathrm{di}-$ vided by the area occupied by this species: $I V p_{i}=I V_{i} / P_{i}$. In this way, the growth of species $i$ in mixed and in pure stands can be compared. Under the hypothesis that growth efficiency (i.e. growth per hectare of available species) will be an expression of site quality, age and density, it may be depicted as a function of dominant height, quadratic mean diameter, and relative density. Since the SNFI data does not contain age as a variable, we used the Assmann stand dominant height $H_{\text {dom }}$ (Assmann, 1970), and the quadratic mean diameter $d_{g}$, as surrogates. Bearing in mind that the mean diameter of a stand will depend on age, density and site quality, this variable will represent age if dominant height and relative density are given. Dominant height at a given $d_{g}$ will then be an expression of site quality. Relative density was expressed by the variable $A$, a measure of the stocking degree based on the same concept as the species proportion by area. This variable is defined as the sum of the areas of fully stocked pure stands of the two species together:

$A=\sum_{i} \frac{G_{i}}{G_{\max _{i}}}$

where $G_{i}$ is the basal area of the species $i$ and $G_{\max _{i}}$ the potential basal area of the same species. The quotient for each species $\left(G_{i} / G_{\text {max }_{i}}\right)$ represents the area of a fully stocked pure stand of the species $i$ needed to exhibit the observed basal area $G_{i}$.

Additionally it must be determined whether this growth efficiency depends on the admixture of the other species. In other words, if we consider a further hypothesis that the growth efficiency of a species in mixed stands is different from the growth efficiency in pure stands, we end up with a depiction of growth efficiency as follows:

$\operatorname{In}\left(I V_{p}\right)=a_{0}+a_{1} \operatorname{In}\left(H_{d o m}\right)+a_{2} \operatorname{In}\left(d_{g}\right)+a_{3} \operatorname{In}(A)+b_{i} P_{i}+\varepsilon$

where $I V_{p}$ is the volume increment of one species per hectare of its available area, hence, its growth efficiency; $H_{d o m}$ is dominant height, $d_{g}$ is the quadratic mean diameter, $A$ is the stocking degree and $P_{i}$ is the proportion by area of the species $i$. Note that the independent variables $H_{d o m}$ and $d_{g}$ and $A$ represent the dominant height, quadratic mean diameter and the stocking degree of the plot, taking into account all the species together in their calculation.

Additionally, interactions between species proportion by area and stocking degree and between species proportion by area and dominant height were tested by including the product of these in the model as independent variables.

Two models were fitted for $P$. sylvestris, and F. sylvatica respectively. The linear regression was fitted using the least squares approach with the $R$ software. A significance level $p<0.05$ was considered.

\section{Results}

\subsection{Maximum basal area in pure stands}

Reineke's maximum stand densities, obtained from the densest pure stands in the SNFI, were as follows:

Pinus sylvestris:

$N_{\max }=362558.5 d_{g}^{-1.750}$
Fagus sylvatica:

$N_{\max }=330087.4 d_{g}^{-1.789}$

where quadratic mean diameter $d_{g}$ is in cm and stand density $N$ is stem/ha.

Once Reineke's maximum stand density is known, the Competition Density Rule depends on only two parameters, which were estimated for each species by fitting Eq. (5). The estimated parameters, all of which were found to be statistically significant, are shown in Table 4.

Using Reineke's maximum stand density and the estimated coefficients of the Competition Density Rule, the equations for maximum basal area (Eq. (6)) are:

Pinus sylvestris:

$G_{\max }=31.65 H_{d o m}^{0.2155}$

Fagus sylvatica:

$G_{\max }=32.49 H_{d o m}^{0.1468}$

where maximum basal area $G$ is in $\mathrm{m}^{2} /$ ha and dominant height $H_{\text {dom }}$ in $\mathrm{m}$.

\subsection{Growth efficiency of species and total growth in pure and mixed} stands

Although the main model proposed was the same for the two species, it was slightly modified in each case so that only significant coefficients and interactions for each individual species were included. The final models are presented below. The corresponding estimated coefficients and fitting statistics are shown in Tables 5 and 6 , respectively, and the graphs for observed vs predicted and studentized residuals in Fig. 2:

Pinus sylvestris:

$\operatorname{In}\left(I V_{p}\right)=a_{o}+a_{1} \operatorname{In}\left(H_{d o m}\right)+a_{2} \operatorname{In}\left(d_{g}\right)+a_{3} \operatorname{In}(A)+b_{1} P_{F s} \operatorname{In}(A)+\varepsilon$

Fagus sylvatica:

$$
\begin{aligned}
\operatorname{In}\left(I V_{p}\right)= & a_{0}+a_{1} \operatorname{In}\left(H_{d o m}\right)+a_{2} \operatorname{In}\left(d_{g}\right)+a_{3} \operatorname{In}(A)+b_{2} P_{P_{s}} \operatorname{In}(A) \\
& +b_{3} P_{P_{S}} H_{\text {dom }}+\varepsilon
\end{aligned}
$$

In these equations $I V_{p}$ is the growth efficiency of the studied species in $\mathrm{m}^{3} \mathrm{ha}^{-1}$ year $^{-1}$, i.e. the volume increment of this species divided by the species proportion by area, $H_{d o m}$ is the plot dominant height in $\mathrm{m}, d_{g}$ is the plot quadratic mean diameter in $\mathrm{cm}, A$ is the stocking degree, and $P_{P S}$, and $P_{F s}$ are the species proportions by area of $P$. sylvestris, and $F$. sylvatica respectively.

Although the growth efficiency of pine was the highest and of beech the lowest, the relationship between growth efficiency, dominant height and quadratic mean diameter was quite similar for both species: a positive relationship with the dominant height and a negative relationship with the quadratic mean diameter. As both variables were included in the model as surrogates of site quality and age, it may be interpreted as an increase in growth per hectare with increasing site quality and a decrease in growth with increasing age.

\section{Table 4}

Parameter estimates (standard error in parenthesis) for the Competition Density Rule. $n$ is the number of observations and $R^{2}$ is the adjusted coefficient of determination.

\begin{tabular}{lllll}
\hline Species & $n$ & $R^{2}$ & $b_{0}$ & $a_{1}$ \\
\hline Pinus sylvestris & 221 & 0.7720 & $0.3276(0.0346)$ & $0.6464(0.0303)$ \\
Fagus sylvatica & 826 & 0.6139 & $0.1715(0.0282)$ & $0.5491(0.0419)$ \\
\hline
\end{tabular}


Table 5

Estimated coefficient for the final growth models (Eqs. (10) and (11)) of the two species (standard errors in parentheses).

\begin{tabular}{|c|c|c|c|c|c|c|c|}
\hline Species & $a_{0}$ & $a_{1}$ & $a_{2}$ & $a_{3}$ & $b_{1}$ & $b_{2}$ & $b_{3}$ \\
\hline Pinus sylvestris & $\begin{array}{l}0.8821 \\
(0.4185)\end{array}$ & $\begin{array}{l}0.7516 \\
(0.1537)\end{array}$ & $\begin{array}{l}-0.3540 \\
(0.1263)\end{array}$ & $\begin{array}{l}0.4460 \\
(0.0620)\end{array}$ & $\begin{array}{l}-0.6421 \\
(0.1650)\end{array}$ & & \\
\hline Fagus sylvatica & $\begin{array}{l}2.0430 \\
(0.3211)\end{array}$ & $\begin{array}{l}0.5345 \\
(0.1250)\end{array}$ & $\begin{array}{l}-0.6453 \\
(0.0743)\end{array}$ & $\begin{array}{l}0.4958 \\
(0.0568)\end{array}$ & & $\begin{array}{l}0.0662 \\
(0.0070)\end{array}$ & $\begin{array}{l}1.0785 \\
(0.2337)\end{array}$ \\
\hline
\end{tabular}

Table 6

Number of data: $n$, absolute mean error: AME, mean standard error: MSE and adjusted coefficient of determination $R^{2}$ for the final growth models (Eqs. (10) and (11)) of the two species.

\begin{tabular}{lllll}
\hline Species & $n$ & AME & MSE & Adjust $R^{2}(\%)$ \\
\hline Pinus sylvestris & 243 & 0.3368 & 0.4685 & 63.14 \\
Fagus sylvatica & 521 & 0.3841 & 0.5339 & 44.19 \\
\hline
\end{tabular}

Generally, growth efficiency also increased with increasing stocking degree, although there were significant interactions between stocking degree and species proportions, which implies that the effect of admixture of other species on growth efficiency depended on the mixture proportions and stocking degree. Thus, the growth efficiency of pine increases as the proportion of beech increases, although the influence of the beech admixture became less pronounced at higher stocking degrees (Fig. 3 up). The growth efficiency of beech (Fig. 3 down) generally increases with the proportion of pine. However, the effect of the proportion of pine on beech is modulated for both the stocking degree and the dominant height. The combination of these two interactions can result in a positive effect of pine proportion for high dominant heights and stocking degrees or in a negative one when dominant height and stocking degree are simultaneously low (Fig. 4).

In addition, it is important to assess the way in which the overall growth of the two species together is influenced by the admixture. Fig. 5 shows different examples illustrating the effect of dominant height and stocking degree on the stand volume increment. The volume increment calculated for the mixed stand is higher than those which would be expected as a sum of volume increment of pure stands (similar intra and inter-specific interaction, straight lines in Fig. 5), despite the negative effect of pine proportion by area on the growth of beech at low stocking degrees and dominant heights. Transgressive overyielding, higher volume increment than that of the most productive pure stand (pine), is found with a relatively large range of proportions and stocking degrees, as can be seen in the example of Fig. 6.

\section{Discussion}

Whether mixed stands are more productive than pure ones is an issue still under debate (Pretzsch and Schütze, 2009), with differing results being obtained according to the forest ecosystem studied. In this study we found that in Scots pine-beech mixed forests analyzed, the effect of mixing on productivity was generally positive, but depends on stocking degree and dominant height of the stand.

This prevalent positive effect of species admixture on volume growth, might be explained by lower interspecific competition due to niche complementarity caused by contrasting characteristics between the studied species, such as crown morphology, shade-tolerance, root system and architecture (Ruiz de la Torre and Ceballos, 1979). Beech benefits from the presence of pine probably also because of the high intraspecific competition observed in beech. F. sylvatica exhibits low self-tolerance and high space sequestration efficiency, giving it a clear advantage in mixed forests (Pretzsch and Biber, 2005). Milios (2004) also found that an admixture of pine awarded a competitive advantage to beech and for Scots pine, similar positive effect were also identified in pine-broadleaf mixtures with several Quercus species (Brown, 1992; Río and Sterba, 2009; Perot and Picard, 2012). Besides niche complementarity, a facilitation effect associated with broadleaf litter may also occur since the positive effect of beech admixture on pine growth is more evident at low densities, where competition is a less relevant factor. This nutritional effect is not always present and depends on species and environments (Rothe and Binkley, 2001). However, this effect has not yet been studied in pine-beech stands in the study area.

A 'competitive reduction' occurs frequently in mixtures when the interspecific competition for a limiting resource is less than that in the monospecific stand (Kelty and Cameron, 1995). Since limiting resources can change depending on stand development and site, the different types of between-species interactions can also change over the life of the stands or in response to environmental conditions (Tilman, 1988; Holmgren et al., 1997; Pretzsch et al., 2010). The significant interaction effect between pine proportion by area and stand dominant height on beech's growth efficiency model might be related to a higher mixing effect on rich sites, characterized by high dominant heights for a given age. This behavior agrees with that found for beech productivity growing with spruce (Pretzsch et al., 2010), explained by the more severe intra-specific competition in beech stands in rich sites than in poor ones. However, as in our study age is not known, dominant height cannot be directly associated to site quality class and, consequently, it is not possible to study the effect of site conditions on between-species interactions.

Our results highlight the fact that stocking degree is also a key factor in between-species interactions. For beech growth efficiency, the pine admixture effect increased with stocking degree, which indicates a stronger between-species interaction when available resources are less abundant for each tree due to the high density. The abovementioned low level of self-tolerance in beech and its associated advantage in mixed stands may become more relevant at higher stocking degrees. This trend in between-species interactions as stand density increases is supported by the results of experiments in which spacing was a controlled factor (Garber and Maguire, 2004; Amoroso and Turnblom, 2006).

In contrast, in the case of Scots pine's growth, the positive effect of an admixture of beech decreased as stocking degree increased. This behavior might be explained by a change in the more important limiting factors as stocking degree increases. At lower densities, beech litter may facilitate pine growth through an improvement in the nutrient cycle and water storage, since there is sufficient above and belowground growing space. However, at higher densities this facilitation effect may be less apparent due to greater competition for resources. Similar changes in the net effect of competition and facilitation were reported by Pretzsch et al. (2010) for spruce-beech mixtures along an environmental gradient, the benefit for beech increasing at good sites while in the case of spruce, the benefit of beech admixture was more important at poor sites. In this regard, Callaway and Walker (1997) highlighted the difficulty of distinguishing between the effects of competition and facilitation. 

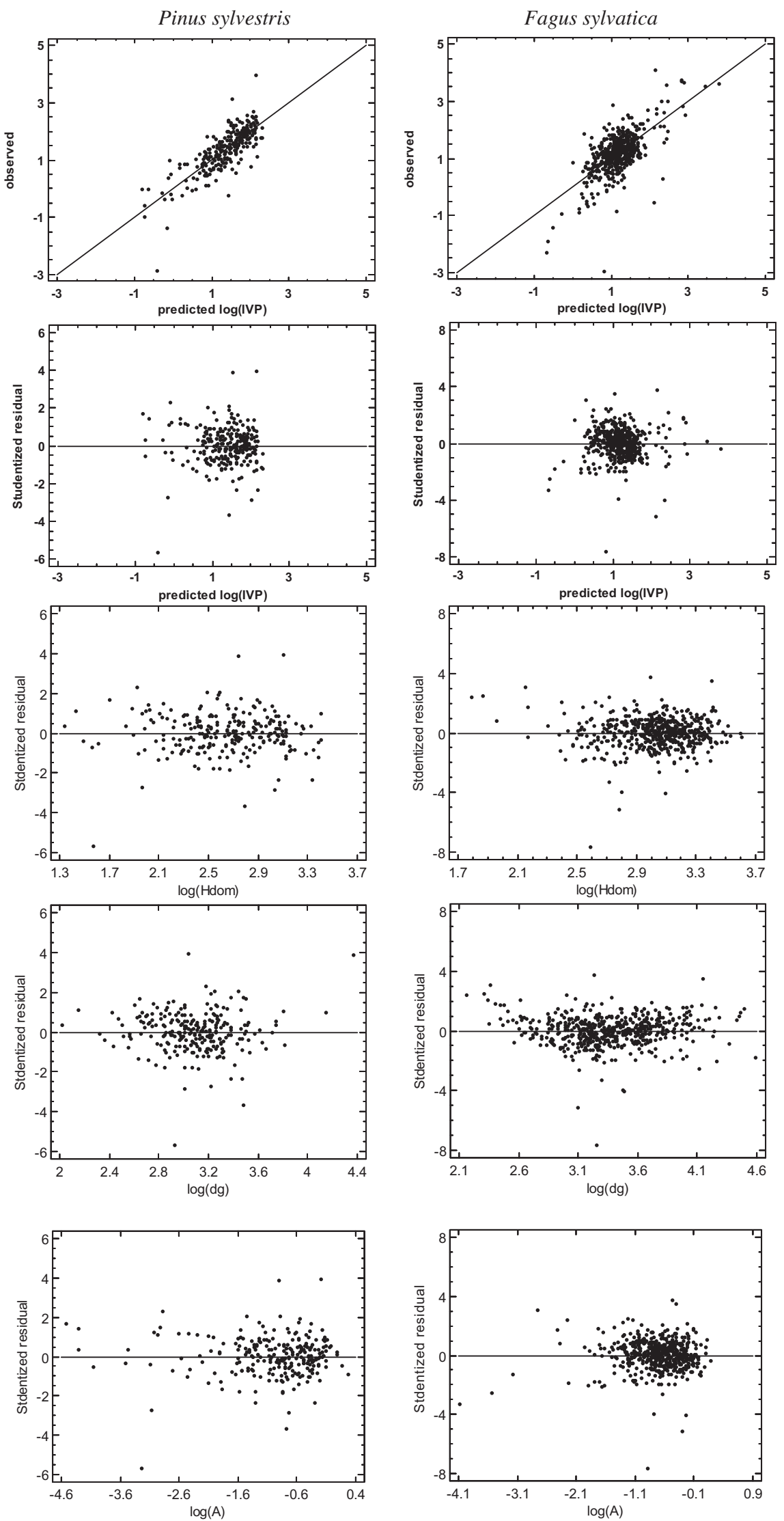

Fig. 2. Fitted vs observed data and graphs of residuals vs predicted and main independent variables of the two growth models (Table 5). 


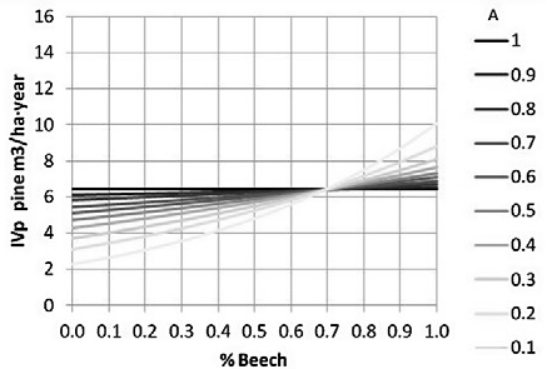

Hdom $=15, \mathrm{dg}=20$

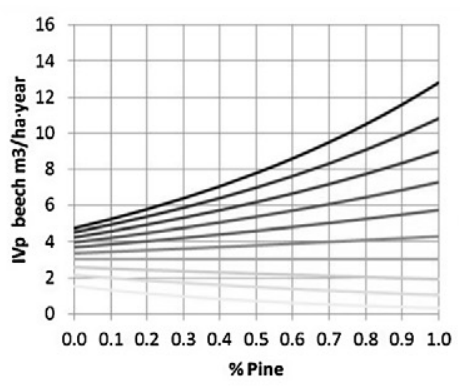

Hdom $=15, \mathrm{dg}=20$

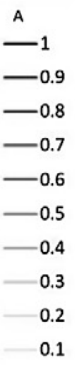

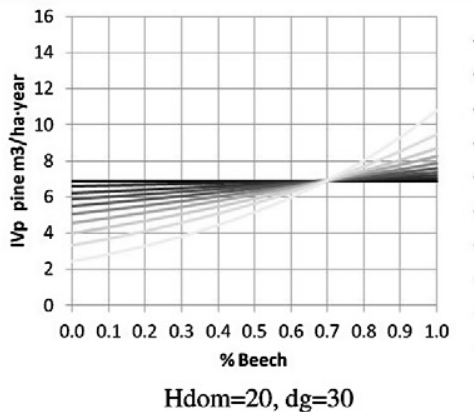

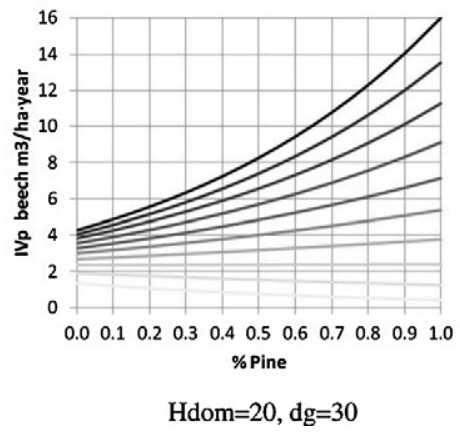

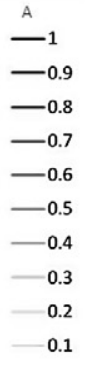

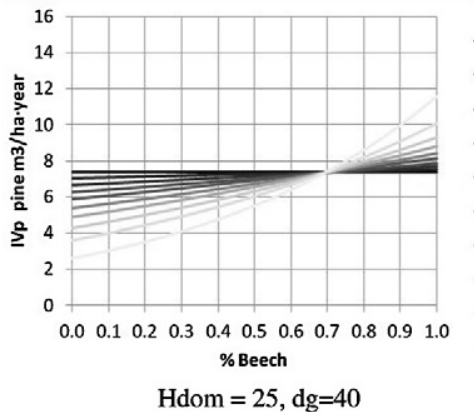

A

$-0.9$

$-0.8$

$-0.7$

$-0.6$

$-0.5$

$-0.4$

0.3

0.2 0.1

$\mathrm{Hdom}=25, \mathrm{dg}=40$

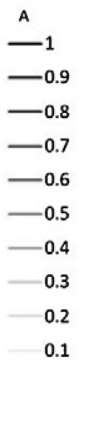

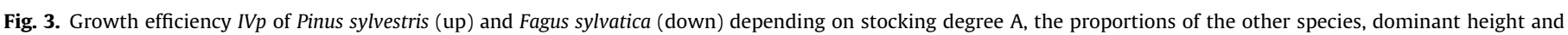
quadratic mean diameter 30 .

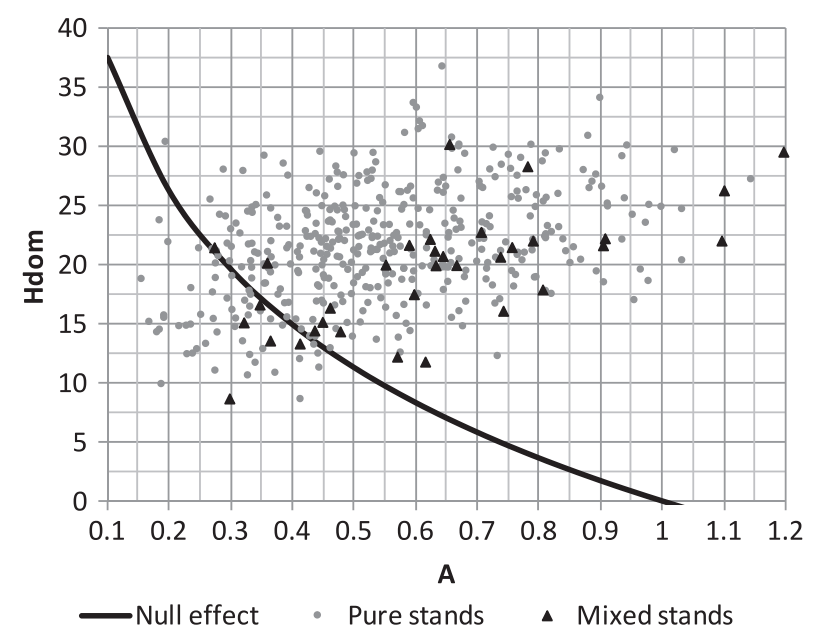

Fig. 4. Data from pure and mixed plots by dominant height and stocking degree. Line shows the values of dominant height and stocking degree which result in a null admixture effect of pine on beech growth efficiency. Values on the right of the curve show pair of values for which the interaction of pine result in a positive effect on beech growth efficiency.

Where P. sylvestris and $F$. sylvestris grow alongside each other in mixed stands, both species exhibit generally higher growth efficiencies and attain higher yields than in their respective pure stands (Fig. 5). This transgressive overyielding effect was also described by Assmann (1970) in a summary of the results obtained in several experiments carried out in $P$. sylvestris-F. sylvatica mixed stands. This higher stand volume growth or transgressive overyielding found with determined proportions of species (i.e. Fig. 6) has important implications for forest management. Diversifying pure stands through the admixture of other species may lead to a small reduction in wood yield but brings with it an increase in other potential benefits such as a higher diversity, greater resilience, etc. (Cannell et al., 1992; Griess and Knoke, 2011). In the study area, this is particularly interesting since the traditionally favoured pure pinewoods can be diversified without an important loss in pine wood production.

The main limitation of the data used is the lack of information about the quality of the site (i.e. site index) and therefore, the results could be confounded by factors other than those included (Vilà et al., 2005). However, relationship between dominant height and diameter have been used as a method of quantifying site productivity for uneven-aged and (or) mixed-species stands (Vanclay and Henry, 1988; Huang and Titus, 1993). So, although we do not use an exact site index according to site index curves, however at a given quadratic mean diameter, dominant height can be understand as a proxy for site quality, avoiding this limitation to some extent. Despite the high variability and large errors that characterize National Forest Inventory data, the variability in volume growth explained by the models is relatively high (Table 6) in comparison to other studies that have used this kind of data source (Río and Sterba, 2009). The results presented in this work for the studied mixtures are reinforced not only by the large number of plots in beech-pine stands, the fit statistic of the models and their biological significance but also by the concordance with the findings of other studies. Nevertheless, the competitive ability of the studied species is expected to vary under different climatic conditions (Meier et al., 2011). Hence, the interspecific relationships identified may differ in other areas or under other environmental conditions.

\section{Conclusions}

The employed methodology can be used to analyze the species admixture effect on growth in mixed stands, even where data from National Forest Inventories is used. We found that the mixing effect in Scots pine-beech stands was mainly positive, with a competition reduction and/or facilitation effect on volume growth of both species. When determined proportions of the different species are present, the interactions can result in transgressive overyielding which has important implications for forest management.

Although previous studies found an increasing effect of mixing on productivity as the stocking degree increases, we found that 

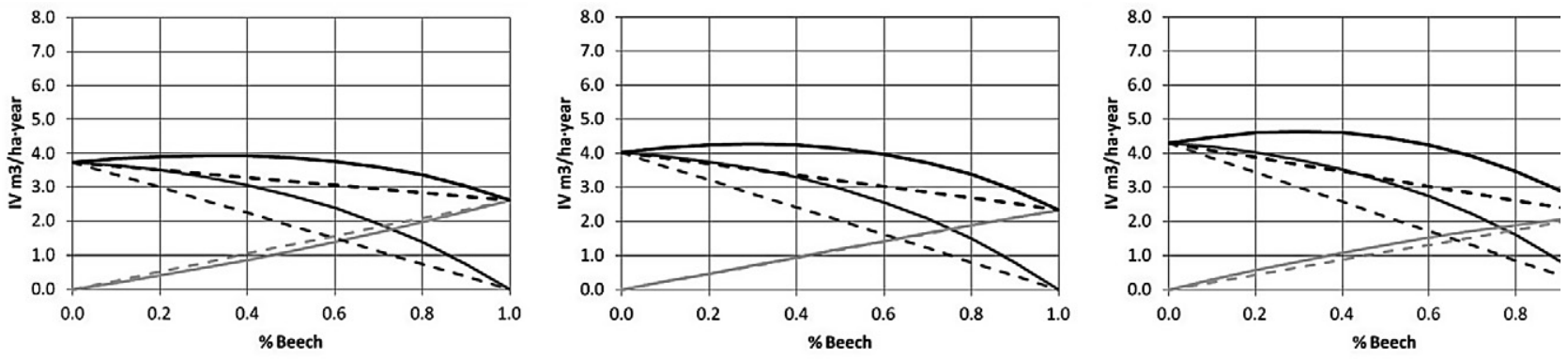

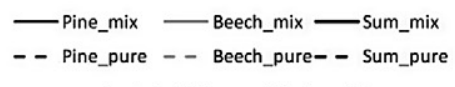

$\mathrm{A}=0.3, \mathrm{Hdom}=15, \mathrm{dg}=20$

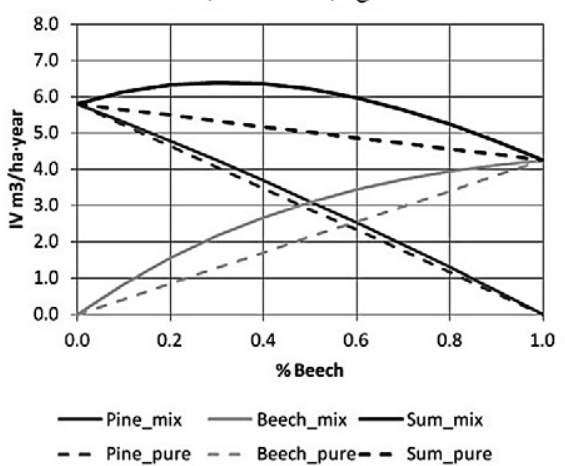

$\mathrm{A}=0.8, \mathrm{Hdom}=15, \mathrm{dg}=20$

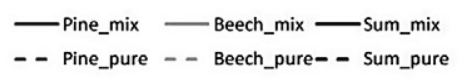

$\mathrm{A}=0.3$, Hdom $=20, \mathrm{dg}=30$

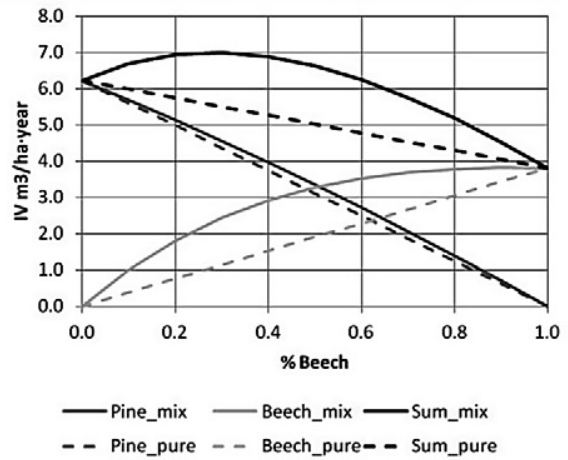

$\mathrm{A}=0.8, \mathrm{Hdom}=20, \mathrm{dg}=30$
-Pine_mix — Beech_mix —Sum_mix

- - Pine_pure - - Beech_pure- - Sum_pure

$\mathrm{A}=0.3, \mathrm{Hdom}=25, \mathrm{dg}=40$

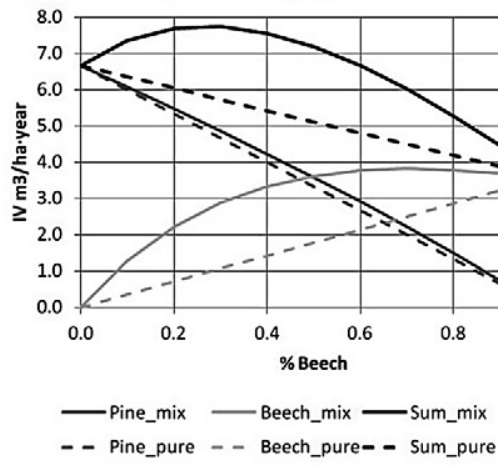

$\mathrm{A}=0.8, \mathrm{Hdom}=25, \mathrm{dg}=40$

Fig. 5. Volume increment of two species growing in pure and mixed stands, depending on stocking degree A, dominant height and admixtures of pine and beech.

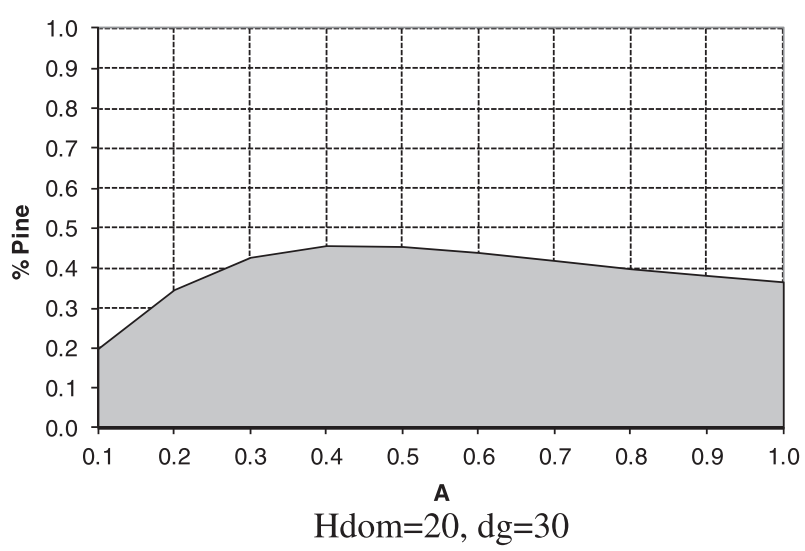

Fig. 6. Grey area shows proportions of pine which result in lower increments than in pure pine stands for different values of stocking degree A.

the interplay between density and mixing effect also depends on species. Thus, a high stocking degree enhances the positive effect of pine admixture on beech growth efficiency, while the influence of beech admixture on pine growth efficiency becomes less pronounced with increased stocking degree. Despite the limitations of our data sources for determining the role of stand density in mixed stands, our findings highlight the importance of this factor in between-species interactions. Future studies concerning productivity in mixed vs. pure stands should focus more closely on the interaction between stocking degree and the effect of mixing on growth.

\section{Funding}

This research was supported by the Universidad Politécnica de Madrid, Departamento de Economía y Gestión Forestal.

\section{Acknowledgement}

We wish to thank Roberto Vallejo, Head of the Spanish National Forest Inventory, for all the data provided.

\section{References}

Amoroso, M.M., Turnblom, E.C., 2006. Comparing productivity of pure and mixed Douglas-fir and western hemlock plantations in the Pacific Northwest. Can. J For. Res. 36, 1484-1496.

Assmann, E., 1970. The principles of yield study. Studies in the Organic Production Structure, Increment and Yield of Forest Stands. Oxford Pergamon Press.

Bartelink, H., 2000. A growth model for mixed forest stands. For. Ecol. Manage. 134 29-43.

Belote, R.T., Prisley, S., Jones, R.H., Fitzpatrick, M., de Beurs, K., 2011. Forest productivity and tree diversity relationships depend on ecological context within mid-Atlantic and Appalachian forests. For. Ecol. Manage.

Bristow, M., Nichols, J.D., Vanclay, J.K., 2006. Improving productivity in mixedspecies plantations. For. Ecol. Manage. 233, 193-194.

Brown, A., 1992. Functioning of Mixed-Species Stands at Gisburn. Blackwell Scientific Publications, NW England, London, pp. 125-150.

Callaway, R.M., Walker, L.R., 1997. Competition and facilitation: a synthetic approach to interactions in plant communities. Ecology 78, 1958-1965.

Cannell, M.G.R., Malcolm, D.C., Robertson, P.A., 1992. The Ecology of Mixed-Species Stands of Trees. Blackwell Scientific Publications.

Cavard, X., Macdonald, S.E., Bergeron, Y., Chen, H.Y.H., 2011. Importance of mixedwoods for biodiversity conservation: evidence for understory plants, songbirds, soil fauna, and ectomycorrhizae in northern forests. Environ. Rev. 19, $142-161$.

Erskine, P.D., Lamb, D., Borschmann, G., 2005. Growth performance and management of a mixed rainforest tree plantation. New Forests 29, 117-134.

Forrester, D.I., Bauhus, J., Khanna, P.K., 2004. Growth dynamics in a mixed-species plantation of Eucalyptus globulus and Acacia mearnsii. For. Ecol. Manage. 193, 81-95.

Garber, S.M., Maguire, D.A., 2004. Stand productivity and development in two mixed-species spacing trials in the central Oregon Cascades. For. Sci. 50, 92105.

Goulding, C.J., 1972. Simulation techniques for a stochastic model of the growth of Douglas-fir. Ph.D Dissertation. The University of British Columbia, Vancouver, Canada, pp. 185.

Griess, V.C., Knoke, T., 2011. Growth performance, windthrow, and insects: metaanalyzes of parameters influencing performance of mixed-species stands in boreal and northern temperate biomes. Can. J. For. Res. 41, 1141-1159. 
Hébert, J., Bourland, N., Rondeux, J., 2005. Estimation de l'accroissement et de la production forestière à l'aide de placettes permanentes concentriques. Ann. For. Sci. 62, 229-236

Holmgren, M., Scheffer, M., Huston, M.A., 1997. The interplay of facilitation and competition in plant communities. Ecology 78, 1966-1975.

Huang, S., Titus, S.J., 1993. An index of site productivity for uneven-aged or mixedspecies stands. Can. J. For. Res. 23, 558-562.

Jogiste, K., 2000. A basal area increment model for Norway spruce in mixed stands in Estonia. Scand. J. For. Res. 15, 97-102.

Kelty, M.J., 1992. Comparative productivity of monocultures and mixed-species stands. In: Kelty M.J., L.B.C., Oliver C.D. (Eds.), The Ecology and Silviculture of Mixed-Species Forests. Kluwer Academic Publishers, Dordrecht (The Netherlands), pp. 125-41.

Kelty, M.J., 2006. The role of species mixtures in plantation forestry. For. Ecol. Manage. 233, 195-204.

Kelty, M.J., Cameron, I., 1995. Plot designs for the analysis of species interactions in mixed stands. Commonw. For. Rev. 74, 322-332.

Kira, T., Ogawa, H., Sakazaki, N., 1953. Intraspecific competition among higher plants. I. Competition-yield-density interrelationship in regularly dispersed populations. J. Inst. Polytechn., Osaka City Univ., Ser. D 4, 1-16.

Meier, E.S., Edwards Jr., T.C., Kienast, F., Dobbertin, M., Zimmermann, N.E., 2011 Cooccurrence patterns of trees along macroclimatic gradients and their potential influence on the present and future distribution of Fagus sylvatica L.J. Biogeogr.

Milios, E., 2004. The influence of stand development process on the height and volume growth of dominant Fagus sylvatica L. sl trees in the central Rhodope Mountains of north-eastern Greece. Forestry 77, 17

MMA, 2002. Plan Forestal Español. Ministerio de Medio Ambiente, Madrid www.mma.es.

Navarra, G.d., 2000. Plan Forestal de Navarra. Publicaciones del Gobierno de Navarra, Pamplona.

Perot, T., Picard, N., 2012. Mixture enhances productivity in a two-species forest: evidence from a modeling approach. Ecol. Res. 27, 83-94.

Porté, A., Bartelink, H., 2002. Modeling mixed forest growth: a review of models for forest management. Ecol. Model. 150, 141-188.

Pretzsch, H., 1999. Modeling growth in pure and mixed stands: a historica overview. In: Olsthoorn, A.F.M., Bartelink, H.H., Gardiner, J.J., Pretzsch, H, Hekhuis, H.J., Franc, A. (Ed.), Management of Mixed-species Forest: Silviculture and Economics. Vol. 15. DLO Institute for Forestry and Nature Research, Wageningen, the Netherlands. IBN Sci. Contrib. pp. 102-107.

Pretzsch, H., Biber, P., 2005. A re-evaluation of Reineke's rule and stand density index. For. Sci. 51, 304-320.

Pretzsch, H., Block, J., Dieler, J., Dong, P.H., Kohnle, U., Nagel, J., Spellmann, H., Zing A., 2010. Comparison between the productivity of pure and mixed stands of
Norway spruce and European beech along an ecological gradient. Ann. For. Sci. 67, 1-12.

Pretzsch, H., Dieler, J., Seifert, T., Rötzer, T., 2012. Climate effects on productivity and resource-use efficiency of Norway spruce (Picea abies [L.] Karst.) and European beech (Fagus sylvatica [L.]) in stands with different spatial mixing patterns. Trees-Struct. Funct., 1-18.

Pretzsch, H., Schütze, G., 2009. Transgressive overyielding in mixed compared with pure stands of Norway spruce and European beech in Central Europe: evidence on stand level and explanation on individual tree level. Eur. J. For. Res. 128, 183-204.

Prodan, M., 1959. Umrechnung von Massen in Flächenanteile. Forstarchiv 30, 110

R, D.C.T., 2011. R: A Language and Environment for Statistical Computing, R Foundation for Statistical Computing, Vienna, Austria.

Reineke, L.H., 1933. Perfecting a stand-density index for even-aged forests. J. Agric. Res. 46, 627-638.

Río, M., Montero, G., Bravo, F., 2001. Analysis of diameter-density relationships and self-thinning in non-thinned even-aged Scots pine stands. For. Ecol. Manage. $142,79-87$.

Río, M., Sterba, H., 2009. Comparing volume growth in pure and mixed stands of Pinus sylvestris and Quercus pyrenaica. Ann. For. Sci. 66, 502.

Rothe, A., Binkley, D., 2001. Nutritional interactions in mixed species forests: a synthesis. Can. J. For. Res. 31, 1855-1870.

Ruiz de la Torre, J., Ceballos, L., 1979. Arboles y arbustos de la España peninsular. Escuela Técnica Superior de Ingenieros de Montes.

Scherer-Lorenzen, M., Körner, C., Schulze, E.D., 2005. Forest Diversity and Function: Temperate and Boreal Systems. Springer Verlag, Berlin, Heidelberg.

Sterba, H., 1987. Estimating potential density from thinning experiments and inventory data. For. Sci. 33, 1022-1034.

Sterba, H., 1998. The precision of species proportion by area when estimated by angle counts and yield tables. Forestry 71, 25-32.

Tilman, D., 1988. Plant Strategies and the Dynamics and Structure of Plant Communities. Princeton University Press.

Vallet, P., Pérot, T., 2011. Silver fir stand productivity is enhanced when mixed with Norway spruce. evidence based on large scale inventory data and a generic modeling approach. J. Veg. Sci. 22, 932-942.

Vanclay, J.K., Henry, N.B., 1988. Assessing site productivity of indigenous cypress pine forest in southern Queensland. Commonw. Forest Rev. 67, 53.

Vilà, M., Inchausti, P., Vayreda, J., Barrantes, O., Gracia, C., Ibáñez, J., Mata, T., 2005. Confounding factors in the observational productivity-diversity relationship in forests. Forest Divers. Funct., 65-86.

Vila, M., Vayreda, J., Comas, L., Ibáñez, J.J., Mata, T., Obón, B., 2007. Species richness and wood production: a positive association in Mediterranean forests. Ecol. Lett. $10,241-250$. 